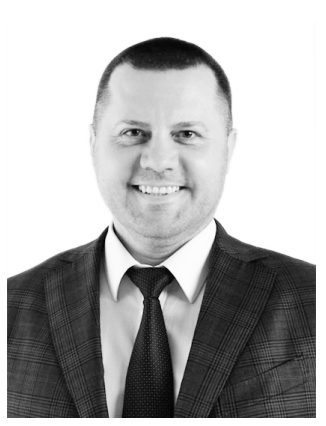

\title{
ЗАЛУЧЕННЯ КАДРІВ У ГАЛУЗІ БЕЗПЕКИ - ІННОВАЦІЙНІ АДМІНІСТРАТИВНО-ПРАВОВІ ЗАСАДИ
} \begin{abstract}
«Вищий навчальний заклад «Міжрегіональна Академія управління персоналом», завідувач кафедри правознавства Сєвєродонецького інституту

ORCID ID: https://orcid.org/0000-0002-7050-5536.

DOI 10.32782/NP.2020.4.10
\end{abstract}

ЛИСЕНКО Сергій Олексійович - доктор юридичних наук, професор, ПрАТ

Статья посвящена анализу современньх подходов к привлечению кадров в области безопасности посредством формирования соответствуюших административно-правовых основ.

Рассмотренъ наиболее распространеннъие подходъ к подбору персонала, среди которых можно вълелить организации, которьие осуществляют набор кадров самостоятельно, а также те, которьие пользуются услугами специализированнъх кадровъх агентств. Вълявлено, что оба подхода пока ориентировань преимущественно на набор персонала из средъг пенсионеров и отставников правоохранительных органов и вооруженных сил, ито обусловлено рядом обстоятельств.

В процессе исследования внимание акцентировано на современных тенденииях активизачии использования информачионнокомпьютернъгх технологий, дистаниионной коммуникации и дистаничонной работъл. В то же время, констатировано возрастание роли личностного подхода к общению с кандидатами на должности, необходимости разработки таких административно-правовых мер управления процессом отбора кадров, которвие будут оптимизировать его с учетом реалий сегодняшнего дня.

Обосновано, ито в современном мире все большую роль играют специалистъ женского пола, которье, несмотря на вездесушую пропаганду гендерного равенства, остаются менее востребованнъими, особенно - в сбере безопасности. При этом, бакторь, которьие ранее обусловливали скептическое отноше- ние к рекрутингу женщин в сббере безопасности - необходимость согласования работь с личной жизнью, бормирование пакета сощиальной зашитьи, необходимость повъчшения комбортности рабочего процесса, нъинче уже не являются определяющими, поскольку в современных условиях все сотрудники ожидают внедрения именно таких условий труда. Таким образом, компании, недостаточно активно привлекающие спещиалистов женского пола, автоматически ставят себя в проигрыиные условия по сравнению с теми компаниями в сббере безопасности, которье стремятся придерживаться гендерного паpumema.

Отдельное внимание посвящено особенностям проведения собеседования, как ключевого этапа отбора персонала. Правильно организованное собеседование позволяет не только повъгсть вфббективность рекрутинга, но и способствует бормированию бренда компании.

Ключевъе слова: безопасность, кадровая политика, административно-правовъе основъ, подбор кадров, корпоративная культура, гендернъий паритет, инбормационнъге технологии, квалибикация.

Постановка проблеми та їі зв'язок за найважливішими науковими та практичними завданнями

Високі темпи інформатизації суспільних відносин, обумовлені розвитком інформаційних технологій, впливають і на сферу безпеки. Усе більше елементів системи безпеки 


\section{Кримінальне право, кримінальний процес та криміналістика}

вплітають у себе досягнення комп'ютерних технологій, стає буденністю використання інтелектуальних програм, набувають масового поширення системи відеоспостереження тощо. Водночас, незважаючи на поширення сучасних технологій, а подеколи - й саме 3 огляду на це, дедалі більше зростає значення та роль добору персоналу, здатного ефективно працювати в нових умовах. Дефіцит якісних кадрів для сфери безпеки організацій - це складне явище, причини і рішення якого часто суперечать не лише одне одному, а почасти навіть сучасній економіці. Питання щодо набору і збереження лояльності людського капіталу у цій сфері є гострою проблемою, яка посилюється численними психологічними проблемами сучасних громадян, гендерною нерівністю та сегрегацією в оплаті праці.

Все це дає нам впевненість у своєчасності розгляду питання, про необхідність формування раціональної політики адміністрування найму співробітників у сфері безпеки організації. При цьому окремої уваги заслуговує проблематика не лише добору кращих фахівців у цій сфері, але й збереження їх лояльності у майбутньому.

\section{Аналіз останніх досліджень та публікацій}

У вітчизняній науці управління персоналом наявні численні розробки, орієнтовані на проблематику добору персоналу, а фахівці ряду галузей юридичної науки пропонують чимало робіт, присвячених правовому регулюванню роботи з кадрами. У ході дослідження знайшли своє застосування окремі ідеї, напрацювання таких вітчизняних та зарубіжних дослідників, як $\curlywedge$. О. Воронько, Г. М. Захарчин, А. Маккарті, А. В. Яцишин, Т. С. Шульгіна, які розглядали особливості добору персоналу в сучасних умовах, у тому числі - у контексті гендерної політики.

\section{Виділення не вирішених раніше питань загальної проблеми}

Незважаючи на те, що останніми роками увага до проблематики кадрового забезпечення з урахуванням необхідності дотримання гендерного паритету зростає, досі малодослідженими лишаються такі питання саме у безпековій сфері.

\section{Формулювання цілей статті}

Метою публікації $є$ аналіз сучасних підходів до оптимізації процесу добору персоналу, з огляду на необхідність дотримання гендерного паритету та високу конкуренцію між роботодавцями за висококваліфікованих фахівців.

Виклад основного матеріалу дослідження з обгрунтуванням отриманих наукових результатів

Наразі, як безпекові підрозідли організацій, так і окремі фірми, послуговуються різними підходами до процесу добору персоналу. У той час, коли традиційні канали пошуку кандидатів усе ще лишаються дієвими, дедалі більшої популярності набуває набір персоналу з використанням комунікаційних технологій, гнучкі методи проведення співбесід і нетрадиційна реклама. Особливо гостро цей тренд зарекомендував себе протягом останнього року, що можна пояснити поширенням дистанційної роботи та комунікації, обумовленим комплексом заходів, орієнтованих на протидію COVID-19.

Немає одностайності й у виборі каналу добору персоналу. У той час, як одні, власноруч влаштовуючи зустрічі та співбесіди, констатують загальну нестачу у кандидатів навичок і талантів, характерну неосвіченість у сфері сучасних технологій, інші звертаються за допомогою до спеціалізованих організацій. При цьому, обидві категорії безпекових роботодавців найчастіше покладаються на джерело кадрів, якими є пенсіонери та відставники правоохоронних органів і збройних сил. Такий підхід обумовлено рядом факторів, ключовими з яких, ймовірно, можна вважати наявність пропозиції на ринку праці, що обумовлює схильність таких осіб працювати за меншу платню, звичність до дисципліни, належна фізична підготовка, навики у сфері володіння зброєю. Для кожного 3 наведених підходів характерні недоліки, що випливають 3 одностороннього погляду на безпеку. 3 огляду на те, що для такого підходу не характерні чіткі адміністративно-правові засади, які повинні регламентувати відносини роботодавця й фахівця та якість виконання завдань, рішення про працевлаштування, як і подальші кадрові 
рішення, базуються на суб`єктивних вподобаннях кількох осіб.

Таким чином, можна констатувати нагальну потребу формування універсальних адміністративно-правових засад підбору, залучення та вдосконалення кадрів у сфері безпеки. Більше того, для впровадження цих засад не потрібні фундаментальні законодавчі зміни, оскільки вони запроваджуються на рівні корпоративних норм певної організації або затверджуються договорами про співпрацю [1]. Більш докладно алгоритм будови адміністративно-правових засад підбору кадрів у сфері безпеки пропонуємо розглянути далі.

Першим кроком у стратегії найму співробітників організації є ознайомлення з сучасною культурою ставлення до працівників служби безпеки. Вкрай важливим $\epsilon$ аналіз наявної кадрової політики організації. Які особливості взаємовідносин співробітників практикуються корпоративною культурою? Чи домінує в організації одна стать над іншою? Чи $є$ акцент на збільшенні сегрегації та загостренні гендерних відмінностей? Саме знання сучасної корпоративної культури дозволяє планувати дії та прогнозувати їх наслідки, і є необхідним у випадку впровадження політики активнішого залучення і просування по службі жінок. Як доволі слушно зазначає з цього приводу Г. М. Захарчин, «надзвичайно важливо, щоб кожен працівник розумів напрям розвитку й свою роль у процесі змін. Це повинно стати складником кадрової політики, особливо щодо раціонального використання жіночого потенціалу» [2, с. 88]. Якщо організація прагне до встановлення гендерного паритету в галузі безпеки, то у процесі добору кращих фахівців, доречно буде враховувати наступні міркування.

Наріжним каменем кадрової політики завжди має виступати знання сильних і слабких сторін як організації, так і окремих співробітників. Саме від цих показників слід відштовхуватися, виявляючи уразливі місця всередині організації (в контексті безпеки). I це слід робити, перш ніж наймати співробітників, щоб заповнити наявні прогалини. Тобто вкрай важливо оцінити свою оптимальну концепцію безпеки, наявний стан справ і відмінність між ними, сформувавши рекрутингову стратегію таким чином, щоб не брати на роботу фахівців тільки 3 однієї спеціалізації, залишаючи інші зони повністю або частково незахищеними.

Звісно ж, у процесі добору кадрів досвід може вважатися пріоритетнішим за кваліфікацію. Під час розміщення оголошень 3 вакансіями розумно деталізувати необхідну кількість навичок, які повинен мати кандидат, для виконання поставлених завдань. Адже якщо навіть у кандидатів 6 необхідний досвід, але вони не бачать переліку формальних посадових обов `зків і не можуть порівняти свої навики з колом потенційних завдань, вони можуть не захотіти подавати заяву. Таким чином, недостатньо деталізоване оголошення сприяє втраті частини перспективних співробітників уже на первинному етапі рекрутингу, ще до співбесіди з ними.

Під час призначення нових співробітників у службу безпеки слід попереджувати їх про майбутнє отримання кваліфікації та відповідних сертифікатів, що матиме велике значення і буде гарною відправною точкою. Навчання та постійне підвищення кваліфікації повинно бути окремою адміністративною нормою у відповідному корпоративному документі. Оскільки працівники, при прийомі на роботу, можуть не мати бажаної спеціальності, підвищення кваліфікації пропонує конкретну спрямованість, з якої слід відштовхуватися тим, хто не знає 3 чого почати свій фаховий розвиток [3].

Окремою невід'ємною складовою сучасної організації праці 6 міжособистісні та комунікаційні здібності. Вміння вирішувати проблеми, працювати в командах, співпрацювати і спілкуватися про колег набуває дедалі більшої ваги. Ці навички, з високою ймовірністю, допоможуть виявити потенційні загрози і реалізувати ефективні заходи щодо протидії їм.

Безпека традиційно є сферою діяльності, у якій домінують чоловіки. Однак, ряд науковців сьогодні ставить питання щодо неефективності та архаїчності такого підходу. Так, на думку $\curlywedge$. О. Воронько, яка досліджувала проблеми гендерної політики в системі державної служби, «унаслідок існування стереотипів у державному управлінні потерпає 


\section{Кримінальне право, кримінальний процес та криміналістика}

не тільки жінка, а й державна служба, суспільство, оскільки недостатньо використовується жіночий інтелектуальний потенціал 3 огляду на не рівне представництво жінок і чоловіків на вищих керівних посадах в органах державної влади» [4]. Визнаючи конструктивність такого підходу в цілому, хотіли $б$ зазначити, що не надто доречно акцентувати увагу суто на керівних посадах. Дуже часто жінки є організованими, висококваліфікованими фахівцями, наприклад - у сфері психології, ІТ-технологій. У цьому контексті, недооцінка потенціалу жінок може призвести до нижчої ефективності діяльності організації в цілому.

Ще одним, без перебільшення революційним фактором у рекрутинговому секторі, можна вважати нові адміністративно-правові підходи до перевірки резюме. Використання штучного інтелекту для обробки великих баз даних дозволить 3 високою ймовірністю прогнозувати успіх тих чи інших кандидатів. При цьому, у ході розвитку етики та технологій штучного інтелекту, фахівці у галузі управління персоналом можуть застосовувати ці підходи на професійному і етичному рівні, закріпивши їх відповідним адміністративно-правовим шляхом. Окремої уваги заслуговують і перспективи використання віртуальної та доповненої реальності - як у ході добору персоналу, так і в процесі його подальшої підготовки та перепідготовки [5]. 3 адміністративної ж точки зору, роль штучного інтелекту, на переконання автора, полягатиме в інформуванні осіб, які ухвалюють рішення про прийом на роботу, але не в ухваленні цих рішень.

Водночас, у деяких галузях безпеки практика найму фахівців переходить до нового адміністративно-правового регулювання взаємовідносин з кандидатами, відходячи від старих систем знеособленого відбору кандидатів та роблячи більший акцент на досвід у проведенні особистих співбесід.

Проведене у 2017 році Ларі Маккарті (директором потужної кадрової агенції «The Eastmark Group, Inc.») і його колегами дослідження реакцій кандидатів продемонструвало, що коли кандидати негативно реагують на сам процес відбору, вони в подальшому охоче поширюють інформацію про низьку професійну привабливість організації, що призводить до зниження намірів рекомендувати компанію іншим і відповідно - погіршення попиту на роботу в такій компанії. Організації, орієнтовані на забезпечення високої якості досвіду роботи з кандидатами, з більшою ймовірністю будуть залучати і підтримувати зв'язок 3 найталановитішими фахівцями. Крім того, вони можуть підвищити популярність свого бренду. Це пов'язано з тим, що коли адміністративно-правовим шляхом люди пов'язують себе 3 організацією, їх ставлення буває більш позитивним. Важливо переконатися, що процес відбору кандидатів є практично-орієнтованим та добре продуманим [6, 7, 8].

Великий досвід роботи з кандидатами не тільки збільшує рівень кадрового резерву, а й сприяє залученню нових клієнтів і підтримує лояльність сучасних, зазначається в «Ultimate Guide to Candidate Experience» HireVue. Робота служби підбору персоналу по розміщенню інформації про зміст вакансій, питань для співбесід і прихильності в процесі найму дуже корисна 3 усіх боків. Не менш корисно дізнаватися про інші компанії, які досягли успіху в процесі співбесід по відбору кадрів, і адаптувати їх виграшні адміністративно-правові заходи у власній організації. Компанії, які випускають те, що гарно працює, є величезними джерелами інформації [9].

В опитуванні HireVue за 2018 рік 1,5 мільйони кандидатів вказали, які саме адміністративно-правові заходи слід застосувати організаціям. До таких вони віднесли:

- скорочення терміну прийому на роботу;

- гнучкість інтерв'ю;

- вступні відеоматеріали;

- м'який старт для відповіді на прості запитання;

- відеоінтерв'ю;

- питання, сформульовані на основі сценаріїв;

- тісну співпрацю з рекрутерами і менеджерами по найму;

- короткі терміни подачі заяв (до 15 хвилин);

- інтерв’ю за запитом;

- активне використання відео та мобільних пристроїв протягом усього процесу - від подачі заяв до співбесіди [9]. 
Таким чином, можна вести мову про необхідність, прискорення процедури відбору, за рахунок підвищення інформаційної насиченості цього процесу, причому бажано - правильно підібраною інформацією. Кандидати на зайняття посади цінують свій час, і зацікавлені або в отриманні роботи, або, у випадку невідповідності висунутим вимогам, скоріше - у швидкій відмові, аніж тривалому очікуванні результату. Демонстрація бренду компанії також справляє дедалі більший вплив на кандидатів. Завдяки новим технологіям, відеоінтерв'ю стає одним зі способів, за допомогою якого роботодавці можуть презентувати свій бізнес у потрібній цільові аудиторії, що дозволяє краще окреслити коло кандидатів і персоніфікувати отриманий досвід. Організації, які створюють персоналізоване послання від керівництва, або демонструють фрагмент робочого дня забезпечують інтерес і розуміння того, що традиційна практика рекрутингової роботи просто не здатна передати [9].

Дослідження свідчать, що нестача різноманітності справляє негативний вплив на команду співробітників, заважає повністю розкрити весь потенціал фахівців. Якщо мета керівництва організації - створити різнопланову команду, важливо докласти зусиль для впровадження ефективних адміністративно-правових засад по їх підбору та найму. Талановиті кандидати на ринку праці завжди є, але потрібно постаратися, щоб іх знайти. Наразі реклама в соціальних мережах і нетрадиційні процеси інтерв'ю можуть допомогти організаціям залучити потенційних фахівців і урізноманітнити свій кадровий резерв.

У цьому контексті ми знову повертаємося до необхідності активізації залучення до роботи жінок. Адже середньостатистично, кожен другий потенційний співробітник жінка. Організаційна культура, лідерство і справедливість - це кілька елементів для створення сприятливого та привабливого для жінок робочого середовища. Якщо підрозділ безпеки потребує більшої кількості жінок, слід розглянути ініціативу нових адміністративно-правових засад організації щодо їх захисту.
Як гарний приклад можна навести авіаційну галузь в США, де з метою ширшого залучення жінок запровадили договори про рівну оплату праці, а інші організаційні питання вирішили шляхом перегляду адміністративно-правових процедур найму і просування по службі. До початку 2000-х років в авіаційній промисловості США переважали чоловіки, що обумовлювало дефіцит кваліфікованих кадрів. I для збільшення представництва жінок кадровики опублікували сім слоганів, що стосуються розширення прав, можливостей і створення рівних робочих умов. Вони виступили 3 такими красномовними заявами: «Жінок захищають!»; «Жінки займають місця за будь-яким столом!»; «Жінки озброєні!»; «Жінки почуті!»; «Жінки цінуються в рівній мірі з чоловіками!» «Жінки гідні!»; «Жінки закликають інших «йти далі»! Така гнучка адміністративно-правова політика організації в перспективі допоможе залучити ширше коло талановитих фахівців у сфері безпеки. Раніше чимало роботодавців ставилися до найму жінок упереджено, $з$ огляду на високу пріоритетність для жінки саме сім’ї та особистого життя, а не роботи. Однак сучасні дослідження свідчать про те, що компанії, які розуміють важливість балансу між роботою та особистим життям, тепер приваблюють потенційних співробітників поряд з винагородами та пільгами, яких потенційні співробітники шукають на новій роботі [10]. Тобто наразі перспективним $€$ більш гнучкий, «людяний» підхід до управління персоналом. У сучасних розвинених країнах ніхто не хоче працювати в тоталітарних умовах «за ідею».

Ми переконані, що вже у 20-х роках XXI століття штат організацій буде включати п'ять поколінь співробітників які працюють в єдиному адміністративному просторі. Незважаючи на відмінності, як у старшого, так i у самого молодого покоління, завжди існують проблеми, пов'язані з роботою та особистим життям, і адміністративно-правова культура повинна враховувати потреби всіх п'яти генерацій. Характер роботи, умови праці, політика та доброзичливе ставлення до працівників - усе це не лише можна, але й потрібно регулювати адміністративно-правовим шляхом, задля впливу на баланс між 


\section{Кримінальне право, кримінальний процес та криміналістика}

роботою та особистим життям [11]. Політика, що враховує інтереси сім'ї, зручний графік роботи, а також догляд за утриманцями, знижує плинність кадрів і впливає на лояльність до організації значно ефективніше, ніж засоби контролю та нагляду.

\section{Висновки}

Впровадження адміністративних заходів, що сприяють знаходженню балансу між роботою та особистим життям, пов'язане 3 підвищенням продуктивності праці, зменшенням загроз від прогулів, скороченням накладних витрат і поліпшенням процесів набору та мотивації персоналу. Організації, які впроваджують стратегічні адміністративно-правові засади забезпечення гнучкості між роботою та особистим життям, підвищують загальну ефективність робітників організації, за рахунок залучення до праці більш кваліфікованих кандидатів і скорочення числа протиріч між роботою та особистим життям.

Формування та впровадження зазначених адміністративно-правових засад вимагає адміністративних зусиль, формування інституту лідерства, справедливості у відносинах, спрямованих на заохочення до розмаїття та згуртованості. Незалежно від сфери діяльності, розміру і складності організації, запропоноване робоче місце може стати важливим фактором для залучення кращих фахівців 3 безпеки. Організації, для оновлення своєї культури безпеки, можуть брати приклад у компаній, які виступають за інновації в підборі і утриманні персоналу, а також за інтеграцію та гендерну рівність. Забезпечення балансу між роботою та особистим життям на відповідному рівні приносить користь як співробітникам, так і роботодавцю.

Побудова майбутніх адміністративноправових засад для забезпечення робочого простору фахівця з безпеки є справжнім викликом для керівництва, вимогою до певної майстерності, яку слід опановувати якомога швидше.

\section{Література}

1. Кодекс законів про працю України: Закон України від 10 грудня 1971p. № 322-VIII (Зі змінами та доповненнями)
URL: https://zakon.rada.gov.ua/laws/show/32208\#Text.

2. Захарчин Г. М. Гендерна політика у стратегії управління персоналом. Науковий вісник Ужгородського національного університету. Серія: Міжнародні економічні відносини та світове господарство. 2019. Випуск 23, частина 1. с. 87-90.

3. Про господарські товариства: Закон України від 19 вересня 1991р. № 1576XII URL: https://zakon.rada.gov.ua/laws/ show/1576-12\#Text

4. Воронько $\lambda$. О. Гендерна політика в системі державної служби: понят-

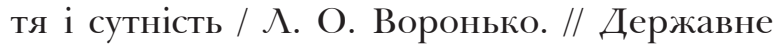
управління: теорія та практика. - 2012. -№ 2. - Режим доступу: http://nbuv.gov.ua/ UJRN/Dutp_2012_2_10

5. Iatsyshyn, A. V., Kovach, V. O., Romanenko, Y. O., Deinega, I. I., Iatsyshyn,A. V., Popov, O. O., . . Lytvynova, S. H. (2020). Application of augmented reality technologies for preparation of specialists of new technological era. Paper presented at the CEUR Workshop Proceedings, 2547, 181-200.

6. Шульгіна Т.С., Сучасні технології підбору персоналу. Науковий вісник Херсонського державного університету, Випуск 23. Частина 3. 2017. 30-33 с.

7. Renovating Your Cybersecurity Hiring. ISSA Journal. September 2019 Volume 17 Issue 9. 5-6 p.

8. The Eastmark Group, Inc. URL: http://www.eastmarkgroup.com/resources/ index.html

9. Executive Grapevine International Ltd, 2020. The Ultimate Guide to Candidate Experience. Download Resource https://www. hrgrapevine.com/resources/register/the-ultimate-guide-to-a-candidate-experience.

10. Авіаційна промисловість СШIA. Український мілітарний портал. URL: https:// mil.in.ua/uk/aviatsiina-promyslovist-ssha/

11. Shvets, V. Y., Rozdobudko, E. V., \& Solomina, G. V. (2013). Aggregated methodology of multicriterion economic and ecological examination of the ecologically oriented investment projects. Naukovyi Visnyk Natsionalnoho Hirnychoho Universytetu, 3, 139-144. 


\section{АНОТАЦІЯ}

Статтю присвячено аналізу сучасних підходів до залучення кадрів у галузі безпеки за допомогою бормування відповідних адміністративноправових засад.

Розглянуто найбільш поширені підходи до добору персоналу, серед яких можна виокремити організащиі, які здійснюють набір кадрів самотужки, а також ті, які користуються послугами спеиіалізованих кадрових агениій. Виявлено, що обидва підходи наразі орієнтовані переважно на набір персоналу з середовища пенсіонерів та відставників правоохоронних органів $i$ збройних сил, що обумовлено рядом обставин.

У прочесі дослідження увагу акщентовано на сучасних тендениіях усе більи активного використання інформаиійно-комп'ютерних технологій, дистаниійної комунікаиї та дистаниійної роботи. Водночас, констатовано зростання ролі особистісного підходу до спілкування з кандидатами на посади, необхідності розробки таких адміністративно-правових заходів управління процесом добору кадрів, який оптимізуватиме його 3 огляду на реалї съогодення.

Обгрунтовано, що в сучасному світі дедалі більшу роль відіграють фахівиі жіночої статі, які, незважаючи на всюдисущу пропаганду гендерної рівності, лишаються мени затребуваними, особливо - у сбері безпеки. При иъому, ббактори, які раніше обумовлювали скептичне ставлення до рекрутингу в безпекову сберу жінок - необхідність узгодження роботи з особистим життям, формування пакету сочіального захисту, необхідність підвищення комбортності робочого процесу, наразі не є визначальними, оскільки в сучасних умовах усі співробітники очікують впровадження саме таких умов праиі. Таким чином, компанї, що недостатньо активно залучають фахівиів жіночої статі, автоматично ставлять себе в програшні умови, порівняно з тими безпековими компаніями, які прагнуть дотримуватися гендерного паритету.

Окрему увагу присвячено особливостям проведення співбесіди, як ключового етапу добору персоналу. Правильно організована співбесіда дозволяє не лише підвищити ефбективність рекрутингу, але й сприяє формуванню бренду компанї.

Ключові слова: безпека, кадрова політика, адміністративно-правові засади, добір кадрів, корпоративна культура, гендерний паритет, інформаиійні технології, кваліфікаиія.

\section{Serhii Lysenko \\ ATTRACTING HUMAN RESOURCES IN THE FIELD OF SECURITY - \\ INNOVATIVE ADMINISTRATIVE AND LEGAL FRAMEWORK}

The article is devoted to the analysis of modern approaches to the recruitment of personnel in the field of security through the formation of appropriate administrative and legal bases.

The most common approaches to recruitment are considered, among which we can single out organizations that recruit on their own, as well as those that use the services of specialized recruitment agencies. It was found that both approaches are currently focused, mainly on the recruitment of staff from among retirees of law enforcement agencies and the armed forces, due to a number of circumstances.

In the process of research the attention is focused on modern tendencies of more and more active use of information and computer technologies, remote communication and remote work. At the same time, the growing role of personal approach to communication with candidates for positions, the need to develop such administrative and legal measures to manage the recruitment process, which will optimize it in view of today's realities.

It is argued that in today's world, female professionals are playing an increasingly important role, but they, despite the ubiquitous promotion of gender equality, remain less in demand, especially in the field of security. At the same time, some of the factors that previously led to skepticism about recruiting in the security sphere of women - the need to reconcile work with personal life, the formation of a social protection package, the need to increase the comfort of the work process, are decisive working conditions now. Thus, companies that do not actively engage female professionals automatically put themselves at a disadvantage compared to those security companies that seek to adhere to gender parity.

Particular attention is paid to the peculiarities of the interview as a key stage of personnel selection. Properly organized interview not only increases the efficiency of recruitment, but also contributes to the formation of the company's brand.

Key words: security, personnel policy, administrative and legal principles, personnel selection, corporate culture, gender parity, information technologies, qualification. 